\title{
Peculiarities of Seizure of Bank Accounts in Criminal Proceedings in Georgia
}

\section{Peculiaridades del embargo de cuentas bancarias en procesos penales en Georgia}

DOI: $10.46932 / \mathrm{sfjdv2n3-069}$

Received in: May 1st, 2021

Accepted in: Jun 30th, 2021

\section{Ketevan Berestova-Gadilia}

Georgia, Ph. D. Candidate in Criminal Law of Faculty of Law of Ivane Javakhishvili Tbilisi State University. Address: Vazha-Pshavela, block 3, building 19, Tbilisi, Georgia;

E-mail: qetevanberestova@gmail.com

\section{Giorgi Matiashvili}

France, Group of Grenoble Academy of Management and Performance-UniMan/CEFERH - Higher European School of Management. Bachelor of International Law. Address: 88 Sh. Nutsubidze Str.,

Tbilisi;

E-mail: mativar199@gmail.com

\section{Naili Pkhikidze}

$\mathrm{PhD}$ of law

Address: 78 P. Kavtaradze Str., Tbilisi, Georgia

E-mail: nai0202@gmail.ru

\begin{abstract}
The article relates to the seizure of bank accounts, its legal bases, submission of collection order and its importance in accordance with the criminal proceedings of the Republic of Georgia.

Property right is the human right acknowledged and protected under the constitution.

"Property right is eternal and supreme human value. Universally recognized basic right is a cornerstone of democratic society, social and legal state. Property is essential basis of human life."

Property right relates to human freedom as exactly under property right is stipulated human existence and proprietary bases of activity that itself has influence on establishment of independent life of human and its management. Thus, each state is obliged to provide environment enabling use of property right. It is negative obligation of state to abstain from such activity stipulating intervention in property right, though under positive obligation the state has to establish such a legal system that will facilitate provision and protection of fair balance between members of society.

"Property right is not only elementary basis of human existence but provides its freedom, adequate realization of person's ability and opportunities, leading the life with personal responsibility. This stipulates private initiatives of individual in the field of economics that facilitates development of economic relations, free entrepreneurship and market economy and normal and stable civil circulation". Social bonding theory is established in legal literature. "Judiciary will not be indifferent to social burden of property as exactly here is exposed the task subject to execution by property, its place, role and importance. That is why social and legal state require both freedom of private property and necessity of its limitation for public purposes."

Itself essence of seizure is interpreted as follows - interim measure prohibiting defendant to alienate seizured property.

The word "seizure" semantically means prohibition, suppression and warning.

Consideration of seizure in terms of the method of etymological study leads us to Europe, where it entered in old England in 1275-1325 and even in the same period in France that was loanword from Latin. Since
\end{abstract}


the 18th century seizure is considered in the monuments of Georgian law. The topic of this article is seizure of bank accounts and submission of collection order.

Keywords: property, property right, its limitation, bank accounts, monitoring, seizure, collection order.

\section{RESUMEN}

El artículo se refiere al embargo de cuentas bancarias, sus bases legales, la presentación de la orden de cobro y su importancia de acuerdo con los procedimientos penales de la República de Georgia.

El derecho de propiedad es un derecho humano reconocido y protegido por la Constitución.

"El derecho de propiedad es un valor humano eterno y supremo. El derecho básico universalmente reconocido es la piedra angular de la sociedad democrática y del Estado social y jurídico. La propiedad es la base esencial de la vida humana".

El derecho de propiedad se relaciona con la libertad humana, ya que el derecho de propiedad estipula exactamente la existencia humana y las bases de propiedad de la actividad que tiene influencia en el establecimiento de la vida independiente del ser humano y su gestión. Por lo tanto, cada Estado está obligado a proporcionar un entorno que permita el uso del derecho de propiedad. El Estado tiene la obligación negativa de abstenerse de intervenir en el derecho de propiedad, aunque tiene la obligación positiva de establecer un sistema legal que facilite la provisión y protección de un equilibrio justo entre los miembros de la sociedad.

"El derecho de propiedad no es sólo la base elemental de la existencia humana, sino que proporciona su libertad, la realización adecuada de la capacidad y las oportunidades de la persona, llevando la vida con responsabilidad personal. Esto estipula las iniciativas privadas del individuo en el campo de la economía que facilita el desarrollo de las relaciones económicas, la libre iniciativa empresarial y la economía de mercado y la circulación civil normal y estable ".

La teoría de la vinculación social está establecida en la literatura jurídica. "El poder judicial no será indiferente a la carga social de la propiedad, ya que aquí se expone exactamente la tarea sujeta a la ejecución de la propiedad, su lugar, su papel y su importancia. Por ello, el estado social y jurídico exige tanto la libertad de la propiedad privada como la necesidad de su limitación para fines públicos".

La esencia misma de la incautación se interpreta de la siguiente manera: medida provisional que prohíbe al demandado enajenar la propiedad incautada.

La palabra "incautación" significa semánticamente prohibición, supresión y advertencia.

La consideración de la incautación en términos del método de estudio etimológico nos lleva a Europa, donde entró en la antigua Inglaterra en 1275-1325 e incluso en el mismo período en Francia que fue loanword del latín. Desde el siglo XVIII la incautación se considera en los monumentos de la ley georgiana. El tema de este artículo es la incautación de cuentas bancarias y la presentación de la orden de cobro.

Palabras clave: propiedad, derecho de propiedad, su limitación, cuentas bancarias, control, incautación, orden de cobro.

\section{INTRODUCTION}

"Actual constitutional and legal enforcement of property right is common for all states aiming establishment of human freedom and progress." 11 It is impossible to have personal and politicalfreedom in modern democratic state without economic freedom that principally is expressed by the freedom of private property. 12 
Property right as the natural and one of the fundamental rights is constitutionally acknowledged and enforced right. 13

In accordance with the constitutional and legal standpoint "property right first of all means subjective and public protection right against state intervention. Guarantee of property with this regard protects property with its specific expression, from separate entity for the enforcement of the latter with the right of personal protection from any unjustifiable intervention."14

Property right is very important for the freedom of individual: "property right is not only elementary basis of human existence, but it provides its freedom, adequate realization of its skill and potentials, direction of life under personal responsibility."15 Property right is protected even under international legal standards. 16

Pursuant to this article is acknowledged human right on peaceful use of personal property; based on its contents together with the right on possession and use of property under propertyright is also considered the right of its free disposal that is traditional and fundamental aspectof property right. Property right is such a natural right without that is impossible to have democratic society. Property right is not only elementary basis of human existence, but it provides its freedom, adequate realization of its skill and potentials, direction of life under personal responsibility."17

Economic power of democratic, legal and social state is exactly based on the respect and protection of property right" 18

Property right as fundamental human right is acknowledged, guaranteed and consolidated under supreme law - Constitution of Georgia. In accordance with the first paragraph, Article 19 of the constitution, "property and heritage right is acknowledged and enforced". The term

- "property is acknowledged and enforced" means protection of legitimate property. There is an assumption that the word "acknowledged" applied in the constitution means guarantee of property inviolability and not its protection, but the word "enforced" means regulation of property right under private law. ${ }^{19}$ Issue of the protection of property right is expressed by state in various legal fields and their respective provisions.

\section{OBJECTIVE AND BASIS OF PROPERTY SEIZURE}

Institute of seizure is ascribed to civil law institute as its essence considers limitation and prohibition of property use. If pursuant to the civil legislation the seizure considers the measure of injunctive relief for the compensation of damage, in this event objective of seizurein criminal procedure is enforcement of possible court verdict. 
In the criminal procedure seizure is the measure of criminal procedural enforcement. In legal doctrine as the measures of lawful procedural enforcement are considered some measures dulymeeting their obligations by the participants of process and prevention of justice on the stages of criminal prosecution or/and court hearing. Procedural enforcement system becomes active when the person participating in the process does not voluntarily fulfil his/her obligation andit is taken into account by law. At the same time the purpose of procedural enforcement is both obtaining evidence and convicted person's conduct enforcement.

There are frequently found many such cases in criminal process, when the item, article and value/asset is both object of seizure and evidence.

Property subject to seizure is regulated under the standards of international law, such as: movable and immovable property, material and nonmaterial evidences and documents indicating or stating right or interest of person on property obtained as a result of offence. Total or partly equivalent of such property, instrument or item of crime, or evidence both onorganized offence and such cases alike: computer crime, murder, trafficking, taking hostage, racism, robbery, falsification of a document, trafficking of vehicles, illegal circulation of worksof art and antiques and others. 20

In criminal procedure seizure of property differs from the institute of seizure of property as the measure of injunctive relief aiming compensation of damage pursuant to the civil legislation. Despite the fact that in both cases proprietor's property right is limited, preconditions, objectives and basis of property seizure are substantially different. 21 "The basis of seizure may not be the only fact of material damaging caused due to wrongful act, as pursuant to the Criminal Procedure Code of Georgia are not acknowledged civil legal requirements in criminal proceeding. And accordingly, is not considered seizure for the compensation of damage." 22

Purpose of seizure is to execute possible court verdict. The verdict is not applied for the compensation of damage to affected persons, though it may even practically provoke aforesaid.

In accordance with the active Criminal Procedure Code, chapter 17 - other procedural activities, namely Article 151 is reflected objective and basis of property seizure, specifically, the first part, Article 151 of Criminal Procedure Code of Georgia is formulated so: "in order tohave carried out criminal coercive measure, possible forfeiture of property the court may under the basis of party's solicitation seizure property of convicted person, or the property of the person materially responsible for its activity or/and the person related to it, including bankaccounts, if there are data that the property will be hidden or spent or/and property is obtainedthrough criminal activity. If there are data that the property is obtained through criminal activity, though it can not be found out, in this event the court is entitled to seizure the property with equal value of this property. In the event of existence of some conditions referred in 
this part, if accused person is official, prosecutor is obliged to solicit to court on theproperty of official, among them about seizure of bank account, also termination of fulfilmentof obligations undertaken based on agreement in the name of state by official or fulfilment ofother activities of injunctive relief.

In accordance with the first part of above mentioned article, purpose of seizure is possible confiscation of property, so only that property is to be seizured that forfeiture is possible in the future. Purpose of property seizure is: 1. meeting conditions of bail applied as a measure of restraint, 2 . maintenance of evidence- when there is a peril of hiding or spending property, 3.obtaining evidence, 4. possible forfeiture of property. At the same time pursuant to the activecriminal legislation is considered essential existence of those circumstances and application of seizure is legal, if there are following circumstances:

1. By all means solicitation of party for the forfeiture of property about its seizure, among them

2. on bank accounts.

Herein is agreed that, property may be seizured and it is legal if we have following conditions:

1. If property is subject or instrument of crime; 2. item subject to crime, also legally obtained property may be seizured, when there is a peril of the use of property through crime; 3 . On property obtained through crime: - a) when property is obtained through crime; b) when property is obtained through corruption; c) obtained through racketeering activity; d) property belongs to the member of criminal society; e) proprietor is convict for the legalization of illegalincomes that will be followed by gaining especially great income; f) income, or property withequal value was gained from above mentioned property through any ways 23 . There are some cases, when upon commitment of crime by convicted person being abroad, his/her property isto be seizured, when citizen of Georgia is convict for such crime that is subject to forfeiture for illegal or/and unproven property in accordance with the civil legislation. In such circumstances prosecutor has a right to appeal against forfeiture of illegal property from convict and its assignment to state within 10 years term after entrance into force of court judgment passed by Criminal Case Chamber at Supreme Court. 24

If there are even one of the aforesaid cases, party may require seizure. Also it is essential to have reasonable doubt stating:

1. That the property will be used, or/and hidden,

2. Or/and property is obtained through crime.

Reasonable doubt/standard of hiding or/and use of property approved for the solicitation about seizure is to be related only to the subject or/and instrument of crime, item aimed for the commitment of 
crime, property obtained through crime.

Seizure may be imposed to convict, materially responsible person, or/and property related to aforesaid person. In order to have imposed seizure it is essential for the person to be accused of that crime at the moment of solicitation to court that is the reason of seizure and to have the status of convicted person at the time of seizure.

Property of convicted person will be seizured in following cases:

a. if it is possible to forfeit property, b. for the bail of convicted person.

Accused person's property may be seizured if this property is not with the accused person - itis delivered to specialized institution for the storage/moneys and securities, valuables/.

Also, if accused person does not own property, it may be seizured /in the event of import of great amount of bonded or smuggled goods through the vehicle. In such case driver is not an owner of imported goods/.

Goods will be seizured and firstly will be established owner of property, then its relation withthe crime. When official is accused, prosecutor is obliged to solicit to court: a./about seizure official's property/bank accounts; $b$ / if official has concluded agreement in the name of state and has undertaken obligations, about suspension of such activity or injunctive relief.

If person undertaking responsibility on accused person's action, whose property is to be seizured, in such case materially responsible person's property will be seizured for the activityof accused person.

Property related to accused person will be seizured if there is a reasonable doubt that the property is obtained as a result of crime committed by accused person and formally recorded to the person related to accused. In accordance with the civil legislation is determined the circle of persons related to accused. The person related to accused may be both his/her familymember and partner and etc.

Pursuant to the Civil Procedure Code is interpreted as to who is the related person. "Person who under the basis of legal documentation owns property and there is a grounded doubt thatit is obtained through racketeering activity or purchased by racketeer, official, member of criminal authority, trafficker, person accused for the promotion of illegal drugs' distribution or person accused for crime determined under Article 194 of criminal code or/and 333 prima article or/and uses property, it is managed by racketeer, official, member of criminal authority,trafficker, person accused for the promotion of illegal drugs' distribution or person accused forcrime determined under Article 194 of criminal code or/and 333 prima article." 25

So, "property registered in the name of related person is to be directly related to the commitment 
of crime."26

"If there is no accused person in the case, neither materially responsible person or/and its related person will exist, accordingly property will not also be seizured."27

Article 151, part 2 of Criminal Procedure Code of Georgia is thus formulated:

"2. Seizure of property determined under this code will be also applied upon preparation of one of the crimes or other especially grave crime determined pursuant to Articles 323, 330 and3311 of Criminal Code of Georgia, also for their restraint, if there are sufficient data stating that this property will be used for the commitment of crime."

Under the basis of this part of article, property may be seizured even if criminal prosecution isnot launched to certain person, though there are data that this property will be used for the commitment of crime at the moment of preparation of especially grave crime.

In accordance with Article 151, part 3 of Criminal Code of Georgia is interpreted following:

3. Court may also seizure property if there are sufficient data that it is the property of the member of corruptive, racketeering, "criminal authority"/"thief in law", or accused person determined under subparagraph "c", part 3, Article 194 of Criminal Code of Georgia or/and crime is committed with regards to this property or/and it is obtained though the crime. Pursuant to its analysis is concluded that it is necessary to state that this property belongs to the member of corruptive, racketeering, criminal authority/thief in law, or/and it is obtained through crime or crime is committed with regards to this property. So, in according with thispart it is not necessary for the accused person to be owner of this property, it is essential to have reasonable doubt that the property is obtained through crime, or crime is committed withregards to the property.

If person is not accused and criminal prosecution is not launched, it is not allowed to seizure property stating that it may be used for the commitment of crime, or/and in order to continuecriminal activity.

If we consider analysis of Article 151, part 3 of Criminal Procedure Code of Georgia, it will be also demonstrated: " seizure may be imposed for: 1. Property obtained through crime, 2. Property subject to confiscation; 3. Property determined for the commitment of especially grave crime - preparation or suppression of crime; 4. Corruptive property; 5. property of the member of criminal society; 6 . Property of person accused for especially great amount of money laundering; 7. Property for that is committed crime.

\section{SPECIFIC FEATURE OF SEIZURE BANK ACCOUNTS}


At the time of seizure of bank account, person's right is limited on management funds existedor registered on his/her bank account. Though, if seizure is applied on determined amount, inthis event is limited person's right on management funds existed on his/her bank account within the scope of seizure. The rest funds may be manages according to personal will.

In aforesaid case it takes place in order not to face peril in the future for the decision making (at the time of seizure of bank account it will not be possible to leave anything from the ownership of defendant).

So, upon application of aforesaid measure, as specific means of interim measure there is to be exactly stated legally advisability of its selection by court". 28

Herein is to be noted that above mentioned prohibition (seizure of property) relates not only to defendant, but even to those third persons, who own this property. In accordance with thislaw are not violated rights of the third persons, as here is not mentioned their property. Though, here may be emphasized that seizure should not be obstructive for the use of this property, if it is not precondition of property destruction, or it does not change its market

a) Physical entity;

Article 198, part 2, subparagraph a) of Criminal Code of Georgia relates even to the seizure of securities and funds that belongs to defendant and is with him/her or other person. In currentcivilized world money is core object of civil relation, as debtor mostly pays to creditor for anyfee. That is why, seizure of funds as injunctive relief may be vital for defendant in order to facedamage that will be uncompensated and unchanged till fulfilment of obligation or end of judicial proceeding.

In accordance with above mentioned issue, Article 198, part 2, subparagraph a) of Criminal Code of Georgia relates even to the seizure of securities and funds that belongs to defendant and is with him/her or other person.

Based on the allocation of funds on bank account for determined term, agreement of money transfer by contractual parties, parties conclude agreement with the bank, who may take loanfor the benefit of aforesaid that is to be fulfilled based on the term, at the same time or in parts. That is why, it is essential to determine as to how strict will be for the defendant, e.g. freezingof bank account and how much damage does it face due to such action, when it has undertakencontractual obligations and the only means of the fulfilment of obligations is banking settlement of accounts. So, taking aforesaid measure is not advisable especially in cases, whenwe have such a relation, when parties have unsecured civil relations under that they have undertaken above mentioned risks of legal relation from the very 
beginning. 30

a) Legal entity;

Seizure of personal account of legal entity may lead creditor to such legal condition, when under provisional measures as a result of delay of entrepreneur's entrepreneurial activity, debtor may not be able to fulfill obligations undertaken before creditor both under personal will and by applying some measures determined in accordance with Law of Georgia on Enforcement Proceedings. Though, it does not mean that if it is impossible to apply proceduralsecurity, it is prohibited to seizure account of legal entity. Nevertheless, it is to be interpretedthat seizure of the account of legal entity may lead to deplorable condition of insolvency. So, when we see expression of free will, it is impossible to apply such provisional measure. Free will should consider the fact stating that in the given case the basis of requirement will be contractual and not delict, meaning that only he/she should decide whether to have unsecuredlegal relation or not. ${ }^{31}$ Prohibition of any action to defendant; based on the essence of injunctive relief, limited right under the measures of relief is to be adequate to the amount of suit. It is not allowed to inconsequently and illegally limit defendant's right under injunctive relief and thus, parties may not be in unequal conditions. 32

In accordance with USA Federal Civil Procedure Law, Article 65 is established the standard on obtaining preliminary prohibitive measure of application, though it is noteworthy that theparty satisfying these preconditions, before the application of certain measures by court, should meet even those criteria that have close relation with some means considered for futureuse. And certain criteria should be sought in federal precedent law. Exactly pursuant to certainfederal laws are legally consolidated measures to be taken by various federal district and its scope. 33

Though herein is to be noted that testimonies of witnesses essential under federal law are to be complete and not convincing. And this is the result of increase of leading efficient procedureby judge. 34

Provisional measures should not be transformed as a mechanism of party's punishment and it should serve to the cases exactly determined under the law. 35 In accordance with the active criminal procedure legislation, when accused person is an official - it is essential:

1. To have seizured entire his/her property, including seizure of his/her bank accounts, also 2.Seizure of his/her bank accounts, 3. If funds are determined for the commitment of such a grave crime alike: terrorism, trafficking, extremism and others.

Seizure of bank account limits the right of entity on administration funds existed andregistered 
on his/her bank accounts within the scope of seizure. At the same time he/she may administer other funds not related to seizure. Specific account of concrete person may be seizured. All accounts registered on the person may be simultaneously seizured./Card, current,currency, deposit/.Also funds registered to him/her in bank safes

Besides the fact that seizure of bank account, or property that is kept in the bank or other credit organization limits property right, at the same time relates to other more important rights by taking appropriate measures. Pursuant to the Law of Georgia on Activities of Commercial Banks, credit organizations and banks warrant their clients on maintenance banksecrecy with regards to client's bank accounts, operations and funds/securities. Bank secrecy is independent object of law. It is a type of confidential information that covers information on the operations, accounts, securities/funds of their clients.

Also under the basis of administration of active legislation, banks and credit and financial organizations have personal data of clients. Above mentioned object of law is protected with the same means alike rights of persons/clients.

Considering the fact that the majority of operations of funds are obtained through crime, by applying banking system in the international documents participating countries have imposedobligation on taking legislative measures allowing courts or/and other competent authorities to accept or/and seizure banking, financial and commercial documents. 36

Upon seizure are discontinued banking operations. Also, at the time of seizure of money and securities there are discontinued financial operations within the scope of that amount as the amount of seizured money or securities.

Account holder is limited and may not spend money from bank account as entire bank accountis seizured and not only amount existed on the account at the moment of seizure. Also personmay not spend amount allocated after the seizure. As we know seizure is time limited and these conditions are active throughout entire approved term. Client may have provided information related to the seizure of account only through the bank.

Essential condition for the seizure of bank accounts is to have provided well-grounded relationto property subject to the seizure to the crime under the investigation.

In practice is allowed and the bank account of the third person may be seizured, if the origin

In accordance with the active Criminal Procedure Code of Georgia is determined possibility of the change of the type of property subject to seizure. If proprietor has other property the person may present proof of actual existence of alternative property and its cost.

Such an alternative is not considered, when accused person is official and it is obligatory to have 
seizured his/her bank account.

If accused person is official both his/her entire property and bank accounts are subject to seizure.

\section{RULE OF SEIZURE OF PROPERTY}

"It is discretionary right of prosecutor to require seizure property that may be applied based on factual circumstances of case and depends on the peril of property damage/devastation/consumption and statement of felonious nature of property.

If accused person is official in this case prosecutor is obliged and not entitled to require seizureof accused person's property, also to require termination of fulfilment of obligation undertakenunder the agreement concluded in the name of state by accused person or other measures of injunctive relief'.

Prosecutor addressed to court in accordance with the place of investigation under grounded solicitation about seizure, to that is also added information essential for its consideration. Information includes: 1. Information about property subject to seizure and copy of identifyingdocument of proprietor about proprietor, 2. Evidences about existence of property subject to seizure.

When bank account is subject of seizure, in this case information about holding bank accountby person is to be included to petition. 38

This information should be grounded stating that certain person has an account in particular bank at the moment of seizure. In practice there are cases when court does not meetsolicitation stating that it is not well-grounded, if account of person in particular bank is not Judge discontinues submitted solicitation with essential information, after it is received withinno later than forty eight hours without oral hearing. Judge has a right to consider such a solicitation with the participation of the author of solicitation. Absence of the author of solicitation is the basis of leaving solicitation without consideration. Court judgment about leaving solicitation without consideration is not subject to appeal. In practice upon urgent necessity there is often arisen issue, when property is to be seizured. If there is a grounded supposition that the property will be concealed or destroyed, in this case prosecutor has a rightto pass a grounded decree about seizure of property. In this case prosecutor has a right to passa grounded decree about seizure of property. Prosecutor is obliged to notify within 12 hours after the enforcement of a decree for the seizure of property (if the expiration of that period falls during non-working hours, within not later than an hour after that period expires), the prosecutor shall inform the court of the seizure of property according to the place of investigation, or the court under the jurisdiction of which the procedural action has been carried out, and shall file a motion requesting the examination of the lawfulness of the seizure, and submit to the court the criminal case materials or their copies that prove the necessity of carrying out the investigative action. Not later than 24 hours after receiving the materials, thecourt shall 
decide the motion without an oral hearing. The court may review the motion withthe participation of the prosecutor and of the person against whom the procedural action has been carried out.

Court is obliged to state in its ruling the amount of property subject to seizure. It inspects urgent necessity, also lawfulness of the process of seizure. If urgent necessity is not establishedduring the process of seizure, but is evident felonious nature of property subject to seizure, inthis event the court is obliged to consider illegal the seizure of property. Based on this circumstance the court does not have restricted right on later or simultaneous consideration and making ruling on the seizure of the same property. Pursuant to Article 156 of Criminal Procedure Code, the ruling on property seizure may be appealed by the prosecutor, the accusedand/or a person whose material rights have been violated as a result of that ruling, as well as by their lawyers. The court ruling on seizure of property shall be handed over to the person authorized to appeal within forty eight hours after the ruling is issued. Court ruling may be appealed only within above mentioned timeframe at investigation panel of the court of appeal.The time limit for appealing a ruling shall commence from the moment of submission of

\section{PROCEDURE FOR ENFORCING A RULING/DECREE ON SEIZURE OF PROPERTY}

Ruling on seizure of property in Georgia is enforced under the basis of Law of Georgia "on Enforcement Proceedings".

First of all money and securities will be seizured.

1. A party shall submit a court ruling and in the case of urgent necessity, a decree of a prosecutor on the seizure of property, to the person who keeps the property, and request the delivery of the property. If that request is denied or there is reliable information that the entireproperty has not been delivered, a search shall be conducted in accordance with this Code.

2. When seizing property, it shall be determined what items and valuables are to be seized within the limits of the amount indicated in the ruling (decree). 40

3. If a bank account is seized, the person's right to administer the funds available on or transferred to his/her bank account shall be restricted. If only a certain amount is seized, the person's right to administer the funds available on or transferred to his/her account shall be restricted within the limits of the seizure. If property has been acquired or increased with theresources obtained in a criminal way, the entire property or its major part may be seized. Seizure shall apply to the property (including that of a legal person and its subsidiarycompanies) of the accused, his/her family member, close relative, related person and/or of a racketeering group, regardless of the share of the accused in that property, provided that thereis sufficient evidence to believe that the property or its part has been obtained as a 
result of racketeering. 41

Investigator/prosecutor submits ruling/decree to banking institution about seizure of bank account and makes a protocol of seizure by the participation of person seizuring property.

\section{PROTOCOL ON SEIZURE OF BANK ACCOUNTS}

Seizure of bank accounts is recorded in appropriate protocol. Upon seizure of bank account after rendering ruling/decree the investigator/prosecutor will submit document/court ruling on seizure, or in urgent necessity decree of prosecutor on seizure of property to banking institution and will make a protocol of seizure by the participation of person seizuring propertyafter that account holder will not be able to access to funds on the account, including neitherthat amount deposited on account after the seizure. Banking institution will notify account holder about seizure.

If property has been acquired or increased with the resources obtained in a criminal way, theentire property or its major part may be seized. Seizure shall apply to the property (includingthat of a legal person and its subsidiary companies) of the accused, his/her family member, close relative, related person and/or of a racketeering group, regardless of the share of the accused in that property, provided that there is sufficient evidence to believe that the propertyor its part has been obtained as a result of racketeering.

\section{CONCLUSION}

Based on presented study we may conclude that seizure of bank accounts is too widespread and established institution in Criminal Proceedings of Georgia. As we see its existence is stipulated by that compulsory circumstance under that bank accounts may be seizuredimmediately as required by law.

Purpose of this article is to have emphasized following issues besides consideration of above mentioned institution:

1. It would be right if the essence of property right limitation is determined under the law.

The term "property right limitation" would be more exactly defined.

2. Also response on author's consideration about bank secret.

\section{BIBLIOGRAPHY}

1. Constitution of Georgia, 24/08/1995.

2. United Nations Convention against Illicit Traffic in Narcotic Drugs and Psychotropic Substances, Strasburg, 19/12/1988.

3. European Convention for the Protection of Human Rights and FundamentalFreedoms as of 1950, additional protocol\# 1, Paris, 20.03.1952. 
4. Europe Convention on Laundering, Search, Seizure and Confiscation of the Proceedsfrom Crime, Strasburg, 08.11.1990.

5. Criminal Code of Georgia, 22/06/1999.

6. Criminal Procedure Code of Georgia, 09/10/2009.

7. Civil Code of Georgia, 26/06/1997.

8. Civil Procedure Code of Georgia, 14/11/1997.

9. Law of Georgia on Enforcement Proceedings, 16/04/1999.

10. Law of Georgia on Activities of Commercial Banks, 23/02/1996.

11. Burduli I., Gotsiridze E., Loria A. and others, Comment of Constitution of Georgia,Tbilisi 2013, 209.

12. Grishashvili I., City Dictionary, Archival Material, prepared for the publication by Kusrashvili R., Tbilisi, 1997, 304.

13. Newspaper "Statements of the Parliament of Georgia", Tbilisi, 24.08.1995, \# 786, Constitution of Georgia, 24.08.1995, Article 19, 31-33.

14. Zoidze T., Essence and Contents of Property Right, Private Law Review, Part 1,Tbilisi, 2015,9 .

15. Izoria L., Korkelia K., Kublashvili K, Khubua G., Comments of Constitution ofGeorgia, Tbilisi, 2005, 145.

16. Kublashvili K., fundamental rights, Tbilisi, 2008, 169.

17. Collection "Decisions of Constitutional Court of Georgia” 2006-2007, Batumi, 2009,195.

18. Collection "Decisions of Constitutional Court of Georgia” 2006-2007, Batumi, 2009, 195.

19. Loladze B., Constitutional and legal Protection of Property Right in Georgia, Collection of Articles \# 1, "Constitutional and International Mechanisms of Human Rights Protection", Tbilisi, 25.12.2010, 99 .

20. Lapachi E., Public Registry - Registration Body of Real Estates and reforms carried out in this field. Magazine "Magazine of Law" \# 2, Tbilisi, 28.06.2009, 82.

21. Loladze B., Constitutional and Legal Protection of Property Right in Georgia" in the collection of articles, "Constitutional and International Mechanisms of Human Rights Protection", Tbilisi, 25.12.2010, 100 .

22. Metreveli V., History of Georgian State and Law, Tbilisi, 2003, 27. 
23. Moniava P., Revazishvili M., Gabisonia N., Gelashvili N., Prosecutorial Law, Tbilisi, 2015,290 .

24. Report of Public Defender of Georgia, 2013,401.

25. Pirtskhalashvili A., Comment of Constitution of Georgia, Georgian citizenship, fundamental human rights and features, Tbilisi, 2013, comment of Article 21, 205.

26. Papiashvili L., ed.. Criminal Procedure Law of Georgia, private part, Tbilisi, 2017, 153.

27. Papiashvili L., Criminal Procedure Law, Private Part, Tbilisi, 2017, 164; 165.

28. Papiashvili L., Comments of Criminal Procedure Code, Private Part, Tbilisi, 2017, 153.

29. Kurdadze Sh., Consideration of Civil Cases at First Instance Court, Second Edition,Tbilisi, 2006, 526.

30. Ruling of Tbilisi Civil Cases Chamber of Court of Appeals as of April 20, 2016 on case \#2b/6144-15.

31. Ruling of Tbilisi Civil Cases Chamber of Court of Appeals as of April 12, 2016 on case \#2b/790-16.

32. Ruling of Tbilisi Civil Cases Chamber of Court of Appeals as of May 11, 2015 on case \#2b/906-15.

33. Ruling of Tbilisi City Court \# 312/6986-14 as of November 14, 2014.

34. Decision made by Constitutional Court of Georgia in July 2, 2007 on case \# 1/384, partof motivation, p. 5.

35. Decision made by Constitutional Court of Georgia in May 18, 2007 on case \# 2/1-370,382, 390, 402, 404, part of motivation.

36. Decision made by Constitutional Court of Georgia in July 21, 1997 on case \# 1/51, 81 .

37. Baicker-Mckee S., Janssen W.M., Corr J.B., A Student's Guide to the Federal Rules of Civil Procedure, West Publishing Company, ST. Paul, Minn, 1997, 613.

38. Cound J. J., Friedenthal J. H., Miller A. R., Sexton J. E., Civil Procedure Supplement,American Casebook series, West Group, ST. Paul, Minn.,1998, 163;164.

39. EU Council Framework Decision 2003/577/JHA of July 2003 on the Execution in the European Union of Orders Freezing Property or Evidence, Part.3,

40. Malmö District Court of 5 August 1991 in Case T 2661/91, Westberg P., Interim Measures and Civil Litigation, Scandinavian Studies In Law 1999-2012, 538.

40. Open-Ended Intergovernmental Working Group on Asset Recovery, Forum for Discussions 
on Capacitybuilding and Technical Assistance, Study Prepared by the Secretariat on Effective Management and Disposal of Seized and Confiscated Assets, Vienna, 24 and 25 August 2017, 15.

41. Ross S., Obtaining Freezing Injunctions in England in Support of Foreign Litigation: Tax Nous and Policing International Fraud in an Era of Transparency. I Turk. Com I..Rcv. Vol. I. NO. 2. June 2015.119.

42. Schwertz M. M., Constitutional Law, Due Process, Prejudgment Seizure of Property,52 Denv, 1975, 619-620.

43. Anisimov A., Melikhov A., Constitutional and Legal Regulation of Private PropertyRight, M. $2009,2$.

44. Grinberg T. and others, Stolen Assets Recovery, (Manual on Confiscation Outside Criminal Proceedings), M., 2010.

45. $\quad$ www.nplg.gov.ge-National parlamentary Library of Georgia $>$.

46. $\quad$ <http://www.supremecourt.ge/files/upload-file/pdf/aqtebi65.pdf $>$.

47. $\quad\langle$ https://www.echr.coe.int/documents/convention_kat.pdf $>$.

48. $\quad\langle$ http://www.supremecourt.ge/files/upload-file/pdf/aqtebi28.pdf $>$.

49. $\quad$ http://www.ombudsman.ge/geo/saqmianobis-angarishebi/saqmianobis-angarishebi- kont $>$.

50. $\quad<$ http://constcourt.ge/ge/legal-acts/judgments/q-tbilisis-chuguretis-raionissasamartloskonstituciuri-wardgineba $>$.

51. $\quad<$ http://constcourt.ge/ge/legal-acts/judgments/q-tbilisis-chuguretis-raionissasamartloskonstituciuri-wardgineba $>$.

52. <https://europa.eu/european-union/about-eu/institutions-bodies/europeancouncil_en $>$.

53. <www.ru.wiktionary.org $>$.

54. <https://www.unodc.org/documents/treaties/UNCAC/WorkingGroups/workinggrou p2/2017August-24-25/V1705952e.pdf $>$.

55. <https://portal.research.lu.se/portal/en/journals/scandinavian-studies-inlaw(07013180-2345-4845-ae9a-baa69c8a744c)/publications.html $>$.

56. <www.unodc.org/documents/corruption/Publications/StAR/StAR_Publication__Non-conviction-based_Asset_Forfeiture_R.pdf $>$. 